\title{
EHMTI-0334. Chronic migraine in young age: clinical characteristics in a prospective chronic migraine registry
}

\author{
M Ruiz", MI Pedraza, C de la Cruz, C Rodríguez, MS Hernandez, M de Lera, I Muñoz, R Moreno, J Barón, \\ A Guerrero
}

From 4th European Headache and Migraine Trust International Congress: EHMTIC 2014 Copenhagen, Denmark. 18-21 September 2014

\section{Introduction}

Chronic migraine $(\mathrm{CM})$ prevalence peaked in midlife, but it is also present among young age.

\section{Aim \\ We aimed to analyze characteristics of young patients in a CM prospective registry.}

\section{Methods}

Patients firstly attended in an outpatient headache office in a tertiary hospital (January 2013-May 2014). CM diagnosed accordingly to ICHD-2R criteria. We gathered demographic and clinical data including comorbidities and risk factors. Patients were classified in two groups, from 14 to 25 years old (Group A), and older than 25 (Group B).

\section{Results}

218 patients (34 males, 184 females), mean age of $40.2 \pm$ 14.2 years (14-71) were diagnosed of CM. 36 cases (16.5\%, 8 male, 28 female) were included in Group A. Among young patients, considering risk factors, in 15 (41.7\%) stressful life events, in $2(5.6 \%)$ mood disorders, and in 3 (8.4\%) obesity. Among comorbidities, in 17 cases (47.2\%) vascular risk factor, especially smoking, in 2 (5.6\%) respiratory disease and no case with other chronic pain. 5 of 28 female patients $(17.8 \%)$ described menstrually-related migraine. When comparing both groups, age at onset of migraine ( $13.1 \pm 4.8$ vs $19.3 \pm 9, \mathrm{p}<0.001)$, time in months from onset of CM $(12.1 \pm 11.3$ vs $48.2 \pm 80.5, \mathrm{p}<0.001)$, and percentage of patients with medication overuse $(27.8 \%$ vs $78.6 \%, \mathrm{p}<0.001)$ and previous preventive therapies
( $27.8 \%$ vs $51.1 \%$, p:0.01) were significantly lower in Group A patients.

\section{Conclusion}

$\mathrm{CM}$ is not uncommon among young age in our registry. Medication overuse is less present in young patients with CM

No conflict of interest.

Published: 18 September 2014

doi:10.1186/1129-2377-15-S1-D24

Cite this article as: Ruiz et al.: EHMTI-0334. Chronic migraine in young age: clinical characteristics in a prospective chronic migraine registry. The Journal of Headache and Pain 2014 15(Suppl 1):D24.
Submit your manuscript to a SpringerOpen ${ }^{\circ}$ journal and benefit from:

- Convenient online submission

- Rigorous peer review

- Immediate publication on acceptance

- Open access: articles freely available online

- High visibility within the field

- Retaining the copyright to your article

Submit your next manuscript at $\gg$ springeropen.com 